\title{
Monsoon Responses to Climate Changes-Connecting Past, Present and Future
}

\author{
Anji Seth $^{1}$ - Alessandra Giannini ${ }^{2,3} \cdot$ Maisa Rojas $^{4} \cdot$ Sara A. Rauscher $^{5} \cdot$ Simona Bordoni $^{6}$ - Deepti Singh ${ }^{7}$. \\ Suzana J. Camargo ${ }^{8}$
}

(C) Springer Nature Switzerland AG 2019

\begin{abstract}
Purpose of Review Knowledge of how monsoons will respond to external forcings through the twenty-first century has been confounded by incomplete theories of tropical climate and insufficient representation in climate models. This review highlights recent insights from past warm climates and historical trends that can inform our understanding of monsoon evolution in the context of an emerging energetic framework.

Recent Findings Projections consistent with paleoclimate evidence and theory indicate expanded/wetter monsoons in Africa and Asia, with continued uncertainty in the Americas. Twentieth century observations are not congruent with expectations of monsoon responses to radiative forcing from greenhouse gases, due to the confounding effect of aerosols. Lines of evidence from warm climate analogues indicate that while monsoons respond in globally coherent and predictable ways to orbital forcing and inter-hemispheric thermal gradients, there are differences in response to these forcings and also between land and ocean.
\end{abstract}

Summary Further understanding of monsoon responses to climate change will require refinement of the energetic framework to incorporate zonal asymmetries and the use of model hierarchies.

Keywords Monsoons $\cdot$ Global warming $\cdot$ Climate changes $\cdot$ Paleomonsoons

\section{Introduction}

In the nearly two decades since its introduction, the concept of a global monsoon, the tropical overturning circulation, and its associated rainfall that responds coherently to the annual cycle of solar forcing [1], has provided a foundation for inquiry that has led to substantial gains in understanding of past, present, and future monsoons [2, 3]. Yet, our understanding remains incomplete. Observational trends in regional monsoons since the 1950s have been inconsistent with theory, evidence from paleoclimate, and climate model projections, and model biases have limited the confidence in projections [4]. How global and

This article is part of the Topical Collection on Climate Change and Atmospheric Circulation

Anji Seth

anji.seth@uconn.edu

Extended author information available on the last page of the article. regional monsoons evolve in the coming decades will most certainly be influenced by anthropogenic drivers, which include greenhouse gases, aerosols, and land use change. Untangling the effects of these external forcings as well as the climate system's internal drivers is of critical importance to our understanding. Here, we digest the recent literature on the response of monsoons to external forcing during past warm periods, and contrast with the forcing and response seen in historical trends in order to better inform monsoon projections.

An emerging theoretical framework interprets monsoons as an integral part of the global atmospheric overturning circulation, and associated energy, angular momentum, and moisture budgets [5], rather than regional land-sea breeze circulations. In this view, monsoons, like the global Hadley cells, are understood as convectively coupled, energetically direct circulations that export the net energy entering the atmospheric column (through surface energy and top-ofatmosphere radiative fluxes) away from their ascending branches and peak precipitation, which nearly coincide with maxima in the near-surface moist static energy $[6,7]$. 
This view is consistent with the projected weakening of monsoon circulations with global warming, (e.g., [8]), despite an increase in land-sea temperature contrast, and the finding that on interannual timescales monsoon strength is correlated with low-level moist static energy gradients, but anticorrelated with low-level temperature gradients $[9,10]$.

The energetic framework has proved particularly powerful in providing theoretical constraints on the position and shifts of the intertropical convergence zone (ITCZ) even in response to forcing at remote latitudes on timescales from seasonal to geologic [11-13]. For an anomalous energy source in one hemisphere, the Hadley circulation can restore energy balance by shifting its ascending branch and ITCZ into the hemisphere with net energy gain and by transporting energy across the equator into the hemisphere with net energy loss, as on average the Hadley cell transports energy across the equator in the direction of its upper-level flow. As discussed by [5], inter-hemispheric energy pertubations usually manifest as inter-hemispheric temperature gradients, primarily at latitudes outside of the tropics, because of the weak temperature gradient constraint in the tropics, with the ITCZ, hence shifting into (away from) the relatively warmed (cooled) hemisphere [14, 15]. For example, the late twentieth century Sahel drought has been attributed to the climate impacts of anthropogenic aerosols through cooling of the northern hemisphere and a southward shift in the tropical rain belt [16]. Since 1980 this inter-hemispheric temperature asymmetry (annual-mean north minus south) has reversed to show a significant positive trend, which is expected to continue to increase throughout the twenty-first century in the Coupled Model Intercomparison Project version 5 (CMIP5 [17]) projections [18].

The energetic framework has emphasized how zonal mean ITCZ shifts are anti-correlated with anomalies in cross-equatorial energy transport, with roughly a 3-degree latitude northward shift for every Petawatt of southward cross-equatorial energy transport [19]. More recent work has, however, shown how changes in the efficiency with which the Hadley cell transports energy can lead to changes in cross-equatorial energy transport even without corresponding shifts in the ITCZ $[20,21]$. Perhaps, more importantly, the emphasis on zonal mean energy budget metrics does not capture changes in monsoons [22], which are zonally asymmetric, and yet responsible for much of the energy transport across the equator during the summer season [23]. Recently, [24] and [25] expanded this framework to include zonal and meridional energy fluxes towards the development of a theory based on energetic constraints for regional tropical rainfall shifts.

This emerging theoretical framework based on global energetic constraints might be the path forward to identify the causes of disagreements between paleo and modern observations, theories, and numerical simulations [4]. Substantial work will be needed to include the complexities of monsoon dynamics (see schematic representation in Fig. 1) in this energetic framework. Meanwhile, comprehensive discussions of monsoons on timescales from tectonic to

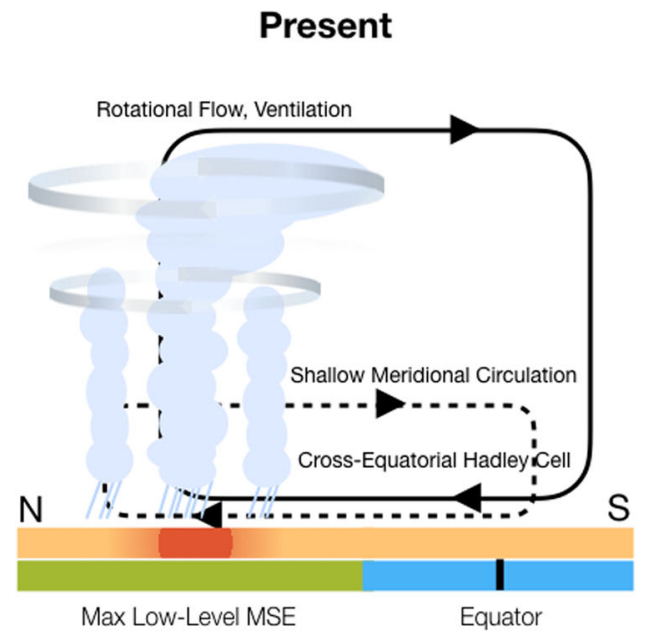

Fig. 1 Mechanistic view of monsoons. Emerging theories interpret monsoons as energetically direct cross-equatorial circulations, integrally linked to the marine ITCZ, and N-S (Hadley) and E-W (Walker) overturning circulations, through global energy budget constraints. The green and blue bar shows land and ocean, respectively. The red and yellow bar shows near-surface moist static energy, where red and orange colors indicate higher moist static energy, and yellow indicates lower values of moist static energy. In the future, the blocks of red
Future

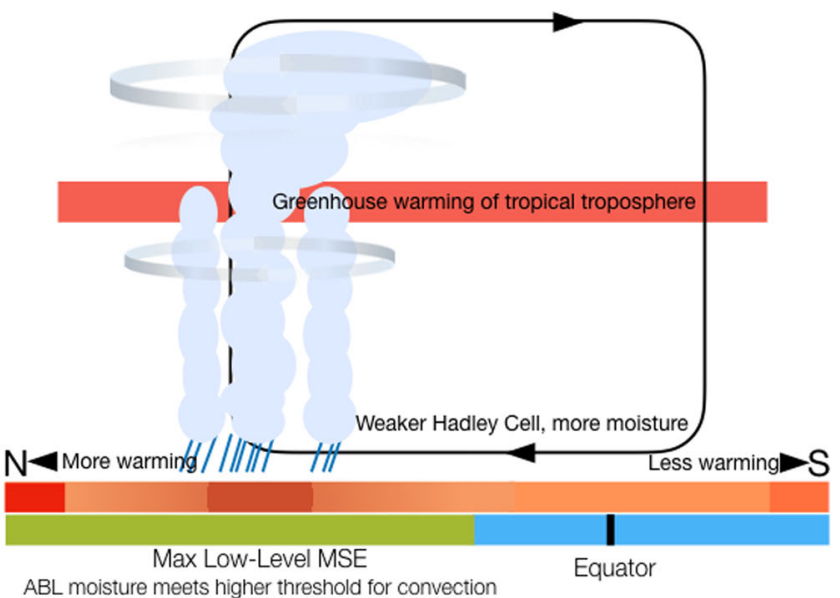

at each end of the bar represent the inter-hemispheric gradient (more warming in the northern hemisphere). The shallow meridional circulation is not shown in the future diagram because changes to it are uncertain. Not all monsoons show a clear cross-equatorial flow, and more work is needed to understand how theories applicable for largescale systems can be modified to other monsoon systems. Adapted from [4] 
intraseasonal [3] have yielded new paleoclimatic insights [2] and mechanisms across timescales [26].

The overall question posed in this review is-in what ways can recent literature on paleomonsoons and historical observed changes inform our understanding of future monsoon responses to anthropogenic forcing? We examine evidence from past warm climates and discuss examples from regional monsoons. It is important to note that most monsoon research to date has yet to consider the implications of the emerging energetic framework at a regional scale, and we include relevant discussions where appropriate. We focus in particular on the implications on rainbelt shifts in response to increased inter-hemispheric temperature contrasts, with the understanding that regional circulation changes, which to date remain poorly understood and constrained, might impact the tropical precipitation response in ways that remain not fully understood. The structure is as follows: We begin with paleomonsoon responses to external forcing during past warm periods. While there are no perfect analogues to the present climate drivers, are there useful insights these warm periods can offer toward understanding present and future changes? We then examine historical and recent changes in monsoons and ask - can new knowledge about the drivers of change (external and internal) in recent monsoon observations help to place observed changes within the context of expected changes based on theory and evidence from past climates? This is followed by a discussion of monsoon projections, with insight gained from past and historical changes. The summary provides a recap of these three main questions regarding the future of monsoons and the potential role of the energetic framework in future monsoon research.

This brief review does not provide a comprehensive summary of recent literature, but rather a selection of recent research, curated to highlight the state of science in response to the questions above. For this reason, not all monsoon regions are equally discussed. Figure 2 presents the monsoons regions (South Asia, East Asia, West Africa, and North and South America) discussed in this review, although details of the region boundaries vary among studies. The South Asian monsoon is part of the larger coupled Asian monsoon system and results from the interaction between the seasonally migrating ITCZ and the Himalayan mountain range [27], while in East Asia monsoon rainfall occurs over East China and along a band across Korea and Japan and into the western North Pacific [28]. The West African/African summer monsoon extends to the Sahel region at its poleward margin. [29]. In the Americas, the North American monsoon region is located in central and northern Mexico and the southwestern USA [30, 31], and the South American Monsoon extends from the Amazon basin southward to Bolivia, Argentina, and Paraguay $[32,33]$.

\section{Paleo Monsoon Responses to External Forcing}

Primary external drivers of past climates include variations in insolation resulting from changes in Earth's orbit, and atmospheric carbon dioxide which affects longwave cooling. Evidence suggests that the long-term $\mathrm{CO}_{2}$ decline over the past tens of millions of years has acted as a driver of global temperature, cooling Earth's climate [34]. These long timescale carbon cycle processes reduced atmospheric $\mathrm{CO}_{2}$ from $\approx 400 \mathrm{ppm}$ in the Pliocene through the Quaternary to pre-industrial levels of $280 \mathrm{ppm}$ [35]. There is evidence that the South Asian and East Asian monsoons have responded to the resulting cooling and ice sheet growth over the past 3.6 M years [26]. At orbital timescales $(\approx 20-100 \mathrm{~K}$ years $)$,

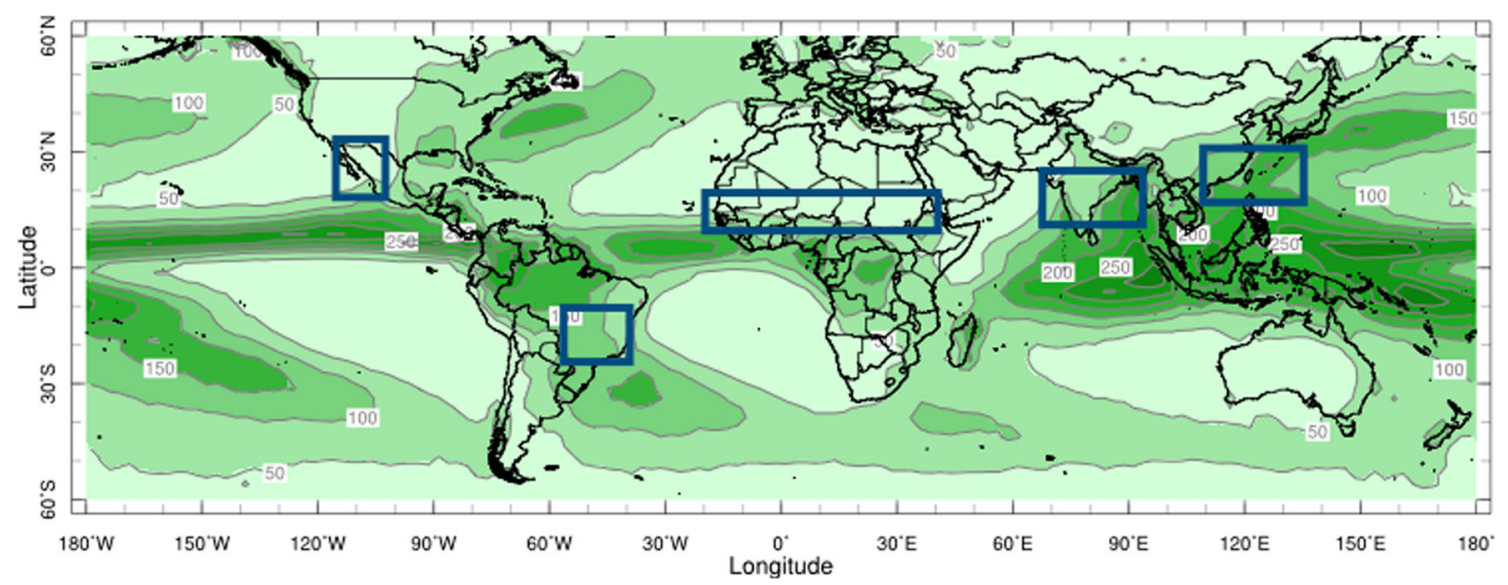

Fig. 2 Observed climatological annual-mean precipitation from Climate Prediction Center Merged Analysis of Precipitation version 2 (CMAP) [146, 147], 1981-2010. Boxes indicate monsoon region boundaries analyzed in this review. Note that reviewed studies consider differing boundaries for these regions 
as seen during the ice advances and retreats of the past $800 \mathrm{k}$ years, $\mathrm{CO}_{2}$ amplifies changes in temperature initiated by orbital variations. It is well established that the cyclic pacing of solar forcing affects the global monsoon system in coherent and largely predictable ways. Earth's precession produces hemispheric antiphased insolation variations in the subtropics and leads to an antiphase response between the northern and southern hemisphere monsoons, albeit with regional differences $[2,3,36]$. In this section, we pose the question: despite the lack of exact analogues, in what ways can the climates of recent warm paleoclimate epochs inform monsoon projections? The relevant literature is summarized in Table 1.

Anthropogenic warming is the consequence of a radiation imbalance at the top of the atmosphere driven by an increase in greenhouse gas concentrations. The main greenhouse gases are well mixed in the troposphere, so that concentration is essentially uniform in the free atmosphere (away from point sources), with $\mathrm{CO}_{2}$ having surpassed $400 \mathrm{ppm}$ in recent years. One could expect that warming would be the same everywhere, but recent studies have pointed to the role of the oceans in breaking the symmetry between northern and southern hemispheres even in present day climate [37]. Under continued greenhouse warming, northern hemisphere polar amplification and southern hemisphere cooling in the circumpolar current might suggest northward ocean heat transport, a shift in the ITCZ toward the warmer northern hemisphere and southward energy transport in the atmosphere via the crossequatorial Hadley cell and monsoons. A positive trend has already been observed in the resulting inter-hemispheric temperature asymmetry since the $1980 \mathrm{~s}$, and is expected to continue to increase through the twenty-first century in the CMIP5 projections [18]. It is important to note that more

Table 1 Monsoon responses for past climates. Analysis type includes models (M) and proxy data (P)

\begin{tabular}{|c|c|c|c|c|c|}
\hline Period & Paper & Region & $\begin{array}{l}\text { Analysis } \\
\mathrm{M} / \mathrm{P}\end{array}$ & $\begin{array}{l}\text { Response } \\
\mathrm{NH} / \mathrm{SH}\end{array}$ & Forcing \\
\hline \multirow[t]{3}{*}{ Review } & Zhishen et al. (2015) & Global & $\mathrm{M} / \mathrm{P}$ & $+/-$ & Orbital \\
\hline & Mohtadi et al (2016) & Global & $\mathrm{M} / \mathrm{P}$ & $+/ 0$ & Precession/obliquity \\
\hline & Wang et al (2017) & Global & $\mathrm{M} / \mathrm{P}$ & $+/-$ & Precession/obliquity \\
\hline \multirow[t]{7}{*}{ Pliocene } & Haywood et al. (2013) & Global & M & $+/ 0$ & PlioMIP \\
\hline & Sun et al. (2013) & EAsia & M & $+/ \circ$ & PlioMIP \\
\hline & Burls, Federov (2014) & Global & M & $+/ \circ$ & $\mathrm{CO}_{2}$, cloud \\
\hline & Zhang et al. (2015) & EAsia & M & $+/ \circ$ & PlioMIP, precession/obliquity \\
\hline & Sun et al. (2016) & EAsia & $\mathrm{M}$ & $+/ \circ$ & PlioMIP \\
\hline & Corvec et al. (2017) & Africa Asia & M & $+/ 0$ & PlioMip \\
\hline & Keuchler et al. (2018) & WAF & $\mathrm{P}$ & $+/ 0$ & Precession/obliquity \\
\hline \multirow[t]{7}{*}{ Eemian } & Otto-Bliesner et al. (2013) & Global & M & $+/-$ & Precession/obliquity \\
\hline & Schneider et al. (2014) & Global & M & +10 & Precession/obliquity \\
\hline & Govin et al. (2014) & WAF & $\mathrm{P}$ & $+/ 0$ & Precession/obliquity \\
\hline & Kathayat et al. (2016) & SAsia & $\mathrm{P}$ & +10 & Precession/obliquity \\
\hline & Singarayer et al. (2017) & Global & M & $+/ \circ$ & Precession/obliquity \\
\hline & Pedersen et al. (2017) & Global & M & $+/-$ & Precession/obliquity \\
\hline & Gierz et al. (2017) & Global & M & $+/ \circ$ & Precession/obliquity \\
\hline \multirow[t]{7}{*}{ Mid-Holocene } & Biasutti et al (2018) & Global & $\mathrm{M} / \mathrm{P}$ & $+1-$ & Precession/obliquity \\
\hline & Braconnot et al. (2012) & WAF & M & $+/ 0$ & Precession \\
\hline & Jiang et al. (2015) & Global & M & $+/ 0$ & Precession \\
\hline & Zhao, Harrison (2012) & Global & M & $+/ \circ$ & Precession \\
\hline & Metcalfe et al. (2015) & NAM & $\mathrm{M} / \mathrm{P}$ & $+/ \circ$ & Precession \\
\hline & Prado et al (2013) & SAM & $\mathrm{M} / \mathrm{P}$ & ০/- & Precession \\
\hline & Baker, Fritz (2015) & SAM & $\mathrm{P}$ & o/- & Precession \\
\hline
\end{tabular}

Precession forcing refers to northern summer perihelion, and obliquity forcing to increased seasonality. PlioMIP forcing employs a pre-industrial orbit, with $400 \mathrm{ppm} \mathrm{CO}$, no ice sheet in West Antartica, a small ice sheet in Greenland, and increased sea level. Response to forcing represents overall stronger $(+)$ or weaker $(-)$ monsoons and is given for northern/southern hemispheres. A ○ represents no information given. Northern Hemisphere (NH); Southern Hemisphere (SH); East Asia (EAsia); West Africa (WAF); and North America (NAM) 
pronounced warming over land is not just a transient feature, but rather a robust response at equilibrium [38]. Despite the increasing temperature asymmetry, a narrowing rather than a clear shift of the ITCZ has been observed [39], and although individual models link simulated ITCZ location to changes in cross-equatorial heat transport, they neither agree on heat transport nor ITCZ shifts [13, 19]. Thus, the response of tropical precipitation to any given forcing is complex and not always in line with expectations.

With this in mind, we consider Earth's recent warm climates and what conditions might qualify as appropriate analogues for anthropogenic greenhouse warming.

\section{Pliocene}

During the early Pliocene (3-5 Mya), $\mathrm{CO}_{2}$ was roughly equivalent to present day while global average temperatures and sea levels were substantially higher, prior to the development of a large Greenland ice sheet. Thus, proxy data and model simulations emphasize an equilibrated climate, while the present climate is transient and in the early stage of response to $\mathrm{CO}_{2}$ forcing. Paleoclimatic records suggest that monsoons across Asia were wetter during the Pliocene. For example, reconstructions using biogenic and lithogenic indices indicate a more intense South Asian summer monsoon prior to the development of northern hemisphere ice sheets around 3.5 Mya [40]. Land and marine-based proxies suggest more rainfall in the East Asian summer monsoon prior to 2.7 Mya, small-amplitude monsoon oscillations between 2.7 and 1.2 Mya, and largeamplitude fluctuations after 1.2 Mya [26, 41, 42]. Proxy data from the Pliocene (both early and mid-Pliocene, 3.23 Mya) also indicate a weakened zonal and meridional sea surface temperature (SST) gradient in the Pacific Ocean, which has been labeled a permanent El Niño-like state [4345]. Pliocene proxy data for southern hemisphere monsoons has not been discussed in the literature to date.

Model experiments carried out for the mid-Pliocene warm period (3.3-2.95 Mya) under the Pliocene Model Intercomparison Project (PlioMIP, [46]) use pre-industrial orbital parameters with two primary experiments: one with prescribed estimated SST and a coupled model simulation. The external forcing is comprised of greenhouse gas concentrations, decreased albedo due to the disappearance of the West Antarctic ice sheet and smaller Greenland ice sheet, and resulting sea level rise. PlioMIP results from both experiments show polar amplification leading to warming in both northern and southern high latitudes with reduced meridional temperature gradient [46]. The reduced equator-to-pole temperature gradient results in a robust weakening of the Hadley circulation [47]. However, the coupled simulations show a less robust weakening of the Walker circulation than those with prescribed SST, which depends on the amount of warming in the tropical Indian ocean [48]. Tropical precipitation shows an expansion in both hemispheres with a decrease near the equator in the prescribed SST experiment, while the coupled experiment indicates a northward shift in the tropical rainbelt. Stronger East and South Asian monsoons are robust in both types of experiments [48-51]. It should be noted that the coupled model experiments using the PlioMIP forcing have difficulty in reproducing SST values and meridional temperature gradients in agreement with paleo proxies.

In a modeling study unrelated to PlioMIP, a climate similar to the Pliocene is simulated by modifying cloud radiative properties. In this simulation, a weakened overturning or negative dynamical change translates into drying in the tropical cores of convection and wetting at the poleward margins of monsoons in both hemispheres [52]. Because the primary forcing applied in these experiments (reduction of meridional cloud albedo) is quite different from those employed in the coordinated PlioMIP experiments, it is difficult to identify precisely the cause of the agreement or disagreement in the details of regional monsoon responses (e.g., expansion of tropical rainfall versus northward shift).

It has been suggested that present and future greenhouse warming could lead to permanent El Niño, Pliocene-like climate, as seen in the experiments described above [52]. Despite the uncertainties in tropical Pacific variability under global warming, projected changes in the mean state reduce the zonal asymmetry with a robust weakening of the Walker Circulation [53]. In addition, models have been shown to lack processes and feedbacks [54] that might make permanent El Niño conditions more relevant in the future.

\section{Quaternary}

Cooling from the Pliocene led to the Quaternary (which includes the Pleistocene and Holocene epochs) and was marked by the growth of the Greenland ice sheet and orbitally paced glacial-interglacial cycles. During the last interglacial (LIG) prior to Holocene, the Eemian (129$116 \mathrm{Kyr}$ ), atmospheric $\mathrm{CO}_{2}$ was similar to the preindustrial value $(\approx 300 \mathrm{ppm})$ and the orbital configuration (large obliquity, large eccentricity, and perihelion in July) resulted in peak northern hemisphere summer (JuneAugust) insolation $\approx 125$ Kya. The summer radiative forcing was stronger than seen in the mid-Holocene, but annual-mean insolation was slightly lower than preindustrial values [55]. This asymmetry in forcing yielded strong northern hemisphere polar amplification with high latitude temperature increases estimated $\approx 3{ }^{\circ} \mathrm{C}$ warmer than present day. [56].

Modeling studies of the Eemian simulate a global mean annual warming similar to projections in a low emissions scenario, with greater warming at high latitudes than at 
low latitudes [56]. However, the external forcing for the Eemian is the insolation change due to orbital forcing which has a different seasonal response (more warming in boreal summer) than the greenhouse gas forcing of the present and future (more warming in the winters of the two hemispheres). While the LIG is not an exact analog for future warming, proxy reconstructions reveal wetter summer monsoons in East Asia and South Asia [57], West Africa [58], and a drier South American monsoon $[59,60]$. Various modeling studies support the hypothesis that insolation-driven latitudinal temperature gradients drive monsoon intensity, simulating increased West African, South Asian, and East Asian precipitation during the LIG [61, 62]. In West Africa, the particular mechanism involved in strengthening the monsoon is related to a low pressure anomaly over northern Africa which increases the winds and moisture transport from the tropical Atlantic [63], although recently it has been shown, at least on interannual timescales, the heat low and associated shallow circulation might in fact weaken the monsoon through advection of lower level moist static energy air [64].

During the time since the Eemian, paleorecords for the past $100 \mathrm{Kyr}$ indicate a strong correlation between the marine ITCZ position and monsoons [59, 63, 65]. The West African monsoon response suggests that hemispheric asymmetry in forcing may have been important even in the early Pliocene, and may have increased in importance as northern hemisphere glaciations proceeded [66].

Recent model integrations that span the period since the last interglacial suggest a more complex response of tropical rainbelts to, on the one hand, insolation-driven asymmetry, which can result in an expansion/contraction of the rainbelt, versus northern hemisphere cooling (due to the presence of ice sheets or meltwater hosing), which drives a southward shift [22]. Further, the responses differ over land and ocean. Over land, the rain belt appears to be influenced by local insolation and thermodynamic processes, while the response to northern hemisphere extratropical forcing, such as the Dansgaard-Oeschger and Heinrich events that are simulated via freshwater hosing experiments produce a meridional rainbelt shift mainly over oceans [22, 67, 68].

To the extent that projections show that the future warming will not be meridionally uniform $[69,70]$ due to polar/Arctic amplification and the presence of an interhemispheric gradient with warmer northern than southern hemisphere, it makes sense to consider paleoclimate analogues that display an inter-hemispheric difference, specifically, analogues that are warmer in the northern hemisphere such as the Eemian (above), and this is also the case for the mid-Holocene: increased obliquity, and, most importantly, precession phased such that the perihelion occurs near the time of northern hemisphere summer solstice (June).
Lines of evidence from paleoclimatic proxies and modeling studies of the mid-Holocene concur that the African and South Asian monsoons are generally strengthened and southern hemisphere monsoons are weakened $[15,71]$. The expansion of the northern hemisphere monsoon is generally captured by models but underestimated especially over Africa [72-74]. [14, 72] summarize oceanic feedbacks as positive in the case of the African monsoon, but negative in the case of the South Asian monsoon.

Evidence suggests that the North American monsoon system with its peak rainfall occurring in the northern hemisphere summer reached its greatest geographical extent in 6 Kya [75]. CMIP5 models indicate both an expansion and increase in rainfall during this period [74]. After 4 Kya, as autumn insolation declined and the ITCZ tracked south, the modern antiphase pattern between northern (Mexico, Baja Peninsula, and Southwest USA) and southern (Central America and Yucatan Peninsula) regions of the North American monsoon emerged, with summer rain continuing to dominate in the south, but with winter rain becoming more important in the north [75]. In South America, evidence from proxy data indicates drier conditions in monsoon regions of southern and southeastern Brazil, while Northeast Brazil appears wetter during the mid-Holocene, suggesting a weaker (than present day) South American monsoon system $[59,76]$.

\section{Summary: Paleomonsoons}

Overall, the development of coordinated modeling exercises (e.g., PlioMIP, LIG, LGM, mid-Holocene) is useful to test and investigate hypotheses about the role of external forcings (greenhouse gases and orbital parameters, as well as their influence on ice sheets) on monsoons. To date, most of these exercises have been limited to time-slice experiments. Nevertheless, the development and consistent use of forcing datasets across models has yielded results that are comparable and provide some reliability in the evaluation of monsoon responses to past climates.

The mid-Pliocene is not the most appropriate analog for anthropogenic climate change in the near term, as this warm period was equilibrated with no West Antarctic ice sheet and relatively little ice in Greenland. Still, it is useful to examine the potential for a climate future wherein substantial ice loss occurs. For the mid-Pliocene, there is good model agreement with existing proxy reconstructions of a stronger summer monsoon across West Africa and South Asia compared to pre-industrial conditions [48], although it remains unclear whether the response is a symmetric expansion of tropical rainfall versus a northward shift. Furthermore, experiments that include changes in orbital configuration indicate that these variations modulate the monsoon response as expected from the mechanistic 
understanding of orbital pacing of monsoon variability (stronger northern monsoons for orbital configurations that enhance northern summer insolation and vice versa) [50].

The asymmetric insolation forcing of the orbital cycles since the LIG and inclusive of the mid-Holocene provides more instructive, though not exact, analogues for future climate. There is model agreement with paleorecords for intensified African, South Asian, and East Asian monsoons in response to peak northern summer insolation during the last interglacial [57, 58, 61, 62]. However, experiments that span the period since the LIG reveal differences in tropical rainbelt response to asymmetric solar insolation versus northern hemisphere cooling, and the response of land versus ocean that complicate expectations based on the zonal mean energetic framework.

\section{Role of External Forcing in Observed Trends}

To understand historical and recent trends in monsoons, we must consider external as well as internal drivers. Because climate models are the primary means for separating their influence, the categorization of drivers depends on how they are incorporated in the models. In general, we refer to external drivers as those prescribed in models and include natural (insolation changes and volcanic aerosols) and anthropogenic (greenhouse gases, aerosols from fossil fuel combustion, and land use change). Internal drivers are variations generated by interaction within the climate system (air, sea, sea ice, and land).

Let's first set present day insolation within the context of orbital forcing. The current phase of precession, with perihelion in January, suggests wetter southern hemisphere monsoons, but a small eccentricity will limit the effect of precession through the next precession cycle $(\approx$ next $20 \mathrm{~K}$ years). Obliquity is in the middle of its range, yielding moderate seasonality at high latitudes. Because this present orbital forcing is and will continue to be relatively weak for the next several thousand years, greenhouse gas and related anthropogenic forcings are the primary drivers of change. The temperature response to present greenhouse gas forcing shows an inter-hemispheric asymmetry with relatively more warming in the north [18].

Monsoons can also be sensitive to variations internal to the coupled ocean-atmosphere system (see, for example, Figure 3, which shows the variability generated by internal dynamics (gray lines) in a large ensemble of realizations with a single climate model). Modes of internal variability that have unique large-scale influences on the individual regional monsoons include the MaddenJulian Oscillation on intraseasonal timescales, the El NiñoSouthern Oscillation (ENSO) on interannual timescales, and multi-decadal variations in the extratropical oceans known as the Inter-decadal Pacific Oscillation and the Atlantic Multidecadal Oscillation (AMO). However, the extent to which the twentieth century evolution of the AMO itself is internal or externally forced is hotly contested [77, 78].

Mechanisms discussed in the literature have, in many cases, focused on near-surface thermal gradients (see below). We note in advance of this discussion that the nascent view of monsoons as energetically direct circulations emphasizes near-surface moist static energy and associated meridional gradients as more directly linked to the spatial extent and strength of monsoonal circulations than the near-surface temperature gradient $[9,10]$. An intention of this review is to support a shift to this new framework for how we view and understand monsoons. With this background, the recent literature on observed trends is discussed and summarized in Table 2.

Precipitation metrics associated with the "global monsoon" (large-scale seasonal tropical overturning circulation) have been developed and used to quantify the global monsoon, hemispheric monsoons, and their changes [79]. Global monsoon indices computed from observations including land and ocean regions from 1979 to 2008 show increasing trends in total precipitation and total area covered, and because the area has increased more than the total rainfall, a decrease in precipitation intensity [80]. The increasing trend in precipitation is corroborated by [81] for the global and (both) hemispheric monsoon indices from 1979 to 2011 across five reanalysis products.

In contrast, when considering the global monsoons over land only, changes in area and rainfall accumulation from 1949 to 2002 showed an overall weakening trend during the past 54 years, due mostly to changes in the West African and South Asian monsoons [82]. Since the 1950s, anthropogenic aerosols and greenhouse gases have been dominant forcings in Earth's top of the atmosphere energy imbalance (see, for example, Fig. 3, which shows the mean externally forced response (black line) in a single climate model and estimates from two commonly used observational products, GPCP and CMAP, which highlight uncertainties in the observations). The observed precipitation decreases in the monsoon regions of the northern hemisphere (Africa and Asia) through the 1980s have been attributed to increased anthropogenic aerosol emissions [83, 84]. The cooling and stabilizing effects of aerosol forcing countered the greenhouse gas warming in the northern extratropics, creating an inter-hemispheric thermal gradient anomaly that shifted the tropical rainbelt and monsoon precipitation equatorward [13, 85, 86]. As aerosol emissions decrease as a result of policy interventions, the expected polar amplification has resumed with an inter-hemispheric gradient showing enhanced warming and reduced stability in the northern hemisphere. The observed annual-mean inter-hemispheric temperature asymmetry has varied within 
Table 2 Monsoon responses for present and future climates. Analysis type includes observations (O) and models (M)

\begin{tabular}{|c|c|c|c|c|c|c|c|c|}
\hline Region & Paper & $\begin{array}{l}\text { Analysis } \\
\mathrm{O} / \mathrm{M}\end{array}$ & $\begin{array}{l}20 \mathrm{C} \\
\mathrm{C} / \mathrm{P}\end{array}$ & $\begin{array}{l}\text { Forcing or } \\
\text { mechanism }\end{array}$ & $\begin{array}{l}\text { Present } \\
\mathrm{C} / \mathrm{P}\end{array}$ & $\begin{array}{l}\text { Forcing or } \\
\text { mechanism }\end{array}$ & $\begin{array}{l}21 \mathrm{C} \\
\mathrm{C} / \mathrm{P}\end{array}$ & Scenario \\
\hline \multirow[t]{8}{*}{ Global } & Wang et al. (2012) & $\mathrm{O}$ & ০/+ & & ০/+ & & & \\
\hline & Hsu et al. (2013) & M & & & & & ০/+ & $\mathrm{RCP}, 4.5$ \\
\hline & Kitoh et al. (2013) & M & & & & & $-/+$ & $\mathrm{RCP}, 4.5,8.5$ \\
\hline & Lin et al. (2013) & $\mathrm{O}$ & & & ০/+ & & & \\
\hline & Lee et al. (2014) & $\mathrm{O}$ & & & ০/+ & & & \\
\hline & Lee, Wang (2014) & $\mathrm{O} / \mathrm{M}$ & ০/- & & ০/+ & HIST & $-/+$ & $\mathrm{RCP}, 4.5$ \\
\hline & Polson et al. (2014) & $\mathrm{O}$ & ০/- & Aerosols & ০/+ & & & \\
\hline & Hurley, Boos (2015) & $\mathrm{O}$ & $\mathrm{nc} / \mathrm{o}$ & & $\mathrm{nc} / \circ$ & & & \\
\hline \multirow[t]{8}{*}{ South Asia } & Singh et al. (2014) & $\mathrm{O}$ & ০/- & & & & & \\
\hline & Salzmann et al. (2014) & $\mathrm{O} / \mathrm{M}$ & $-1-$ & Aerosols & & & & \\
\hline & Wang et al. (2014) & $\mathrm{O} / \mathrm{M}$ & & & $\mathrm{nc} / \mathrm{nc}$ & HIST & $-/+$ & $\mathrm{RCP}, 4.5$ \\
\hline & Guo et al. (2015) & M & $-/-$ & Aerosols & & & & \\
\hline & Roxy et al. (2015) & $\mathrm{O}$ & $-/-$ & -Gradient & & & & \\
\hline & Walker et al. (2015) & $\mathrm{O}$ & o/nc & & $\circ / \mathrm{nc}$ & & & \\
\hline & Paul et al. (2016) & $\mathrm{O} / \mathrm{M}$ & ০/- & Land cover & & & & \\
\hline & Jin, Wang (2017) & $\mathrm{O} / \mathrm{M}$ & & & $+/+$ & + Gradient & & \\
\hline \multirow[t]{5}{*}{ East Asia } & Zhu et al. (2012) & $\mathrm{O}$ & $-1-$ & Circulation & & & & \\
\hline & Qian, Zhou (2013) & $\mathrm{O}$ & $-1-$ & Trop SST & & & & \\
\hline & Li et al. (2016) & $\mathrm{O}$ & $-1-$ & Aerosols & & & & \\
\hline & Song et al. (2014) & $\mathrm{O}$ & $-/-$ & Aerosols & & & & \\
\hline & Wang et al. (2014) & $\mathrm{O} / \mathrm{M}$ & & & $\mathrm{nc} / \mathrm{nc}$ & HIST & $\mathrm{nc} /+$ & $\mathrm{RCP}, 4.5$ \\
\hline \multirow[t]{7}{*}{ West Africa } & Sanogo et al. (2015) & $\mathrm{O}$ & & & o/+ & & & \\
\hline & Giannini et al. (2013) & $\mathrm{O} / \mathrm{M}$ & ০/- & Aerosol, $\mathrm{CO}_{2}$ & ০/+ & $\mathrm{CO}_{2}$ & & \\
\hline & Biasutti (2013) & $\mathrm{O} / \mathrm{M}$ & ০/- & & ০/+ & $\mathrm{CO}_{2}$ & ○/? & $\mathrm{RCP}, 4 \times$ \\
\hline & Booth et al. (2012) & M & ০/- & Aerosol & & & & \\
\hline & Dong, Sutton (2015) & M & & & $+/+$ & $\mathrm{CO}_{2}$ & & \\
\hline & Wang et al. (2016) & M & $-1-$ & Aerosol & & & & \\
\hline & Hill et al. (2017) & M & & & & & $? / ?$ & $+2^{\circ} \mathrm{K}$ \\
\hline \multirow[t]{6}{*}{ NAM } & Arias et al. (2015) & $\mathrm{O}$ & $? / \mathrm{nc}$ & SSTs & $? / \mathrm{nc}$ & $\mathrm{CO}_{2}$ & & \\
\hline & Hoell et al. (2016) & $\mathrm{O}$ & & & $? / \mathrm{nc}$ & $?$ & ০/+ & $\mathrm{RCP}$ \\
\hline & Petrie et al. (2014) & $\mathrm{O}$ & o/nc & & ○/nc & $?$ & & \\
\hline & Cook, Seager (2013) & M & & & & & o/nc & $\mathrm{RCP}$ \\
\hline & Maloney et al. (2013) & M & & & & & ০/- & $\mathrm{RCP}$ \\
\hline & Pascale et al. (2017) & $\mathrm{O} / \mathrm{M}$ & & & & & ০/- & $2 \times \mathrm{CO}_{2}$ \\
\hline \multirow[t]{5}{*}{ SAM } & Arias et al. (2015) & $\mathrm{O}$ & $? / \mathrm{nc}$ & SSTs & $? / \mathrm{nc}$ & $\mathrm{CO}_{2}$ & & \\
\hline & Skansi et al. (2013) & $\mathrm{O}$ & $? /+$ & & $? /+$ & & & \\
\hline & Grimm, Saboia (2014) & $\mathrm{O}$ & $? /+$ & & & & & \\
\hline & de Carvalho et al. (2016) & $\mathrm{O}$ & & & $? /+$ & $\mathrm{CO}_{2}$ & ○/? & $\mathrm{RCP}$ \\
\hline & Jones, deCarvalho (2016) & M & & & & $\mathrm{CO}_{2}$ & ○/? & $\mathrm{RCP}$ \\
\hline
\end{tabular}

The twentieth century response (20C) is given as stronger (+) or weaker (-) circulation (C) and wetter(+) or drier (-) for precipitation (P) and likewise for the present, and late twenty-first century (21C). A o represents no information given and ? indicate inconclusive results within the $\mathrm{C} / \mathrm{P}$ pair. The observed mechanism or model forcing is given in a separate column to the right of $20 \mathrm{C}$ and present columns. The scenario employed in experiments for the future is given in the column to the right of 21C. Representative Concentration Pathway (RCP); Historical simulation (HIST); no change (nc) 

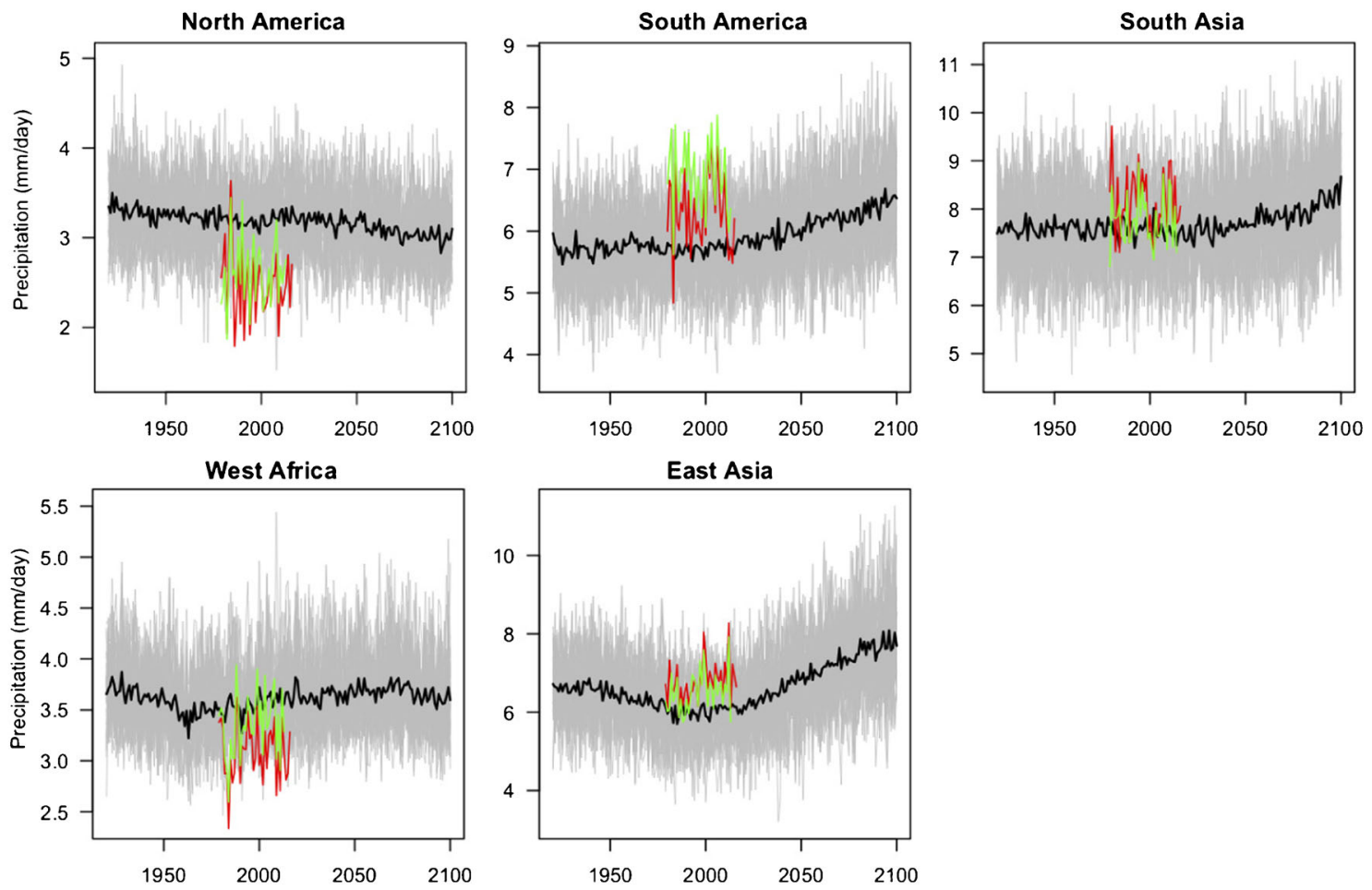

Fig. 3 Time series of regional-average monsoon season precipitation from observations-CMAP [146, 147], (red) and Global Precipitation Climatology Project (GPCP) [148, 149] (green)—for the historical period (1979-present) and the National Center for Atmospheric Research CESM Large Ensemble Project (1920-2100) with all historical forcings from 1920 to 2005 and the RCP 8.5 scenario from 2006 to 2100 [150]. Gray lines indicate the individual ensemble members

and the black line is the 40-member ensemble average. The monsoon domains include South Asia $\left(65-95^{\circ}\right.$ E, 10-25 $\left.5^{\circ} \mathrm{N}\right)$, East Asia $\left(110-135^{\circ} \mathrm{E}, 20-35^{\circ} \mathrm{N}\right)$, West Africa $\left(20^{\circ} \mathrm{W}-40^{\circ} \mathrm{E}, 10-20^{\circ} \mathrm{N}\right)$, North America $\left(115-102.5^{\circ} \mathrm{W}, 17-33^{\circ} \mathrm{N}\right)$, and South America (60$40^{\circ} \mathrm{W}, 10-25^{\circ} \mathrm{S}$ ). The monsoon seasons are defined as June-August for the northern hemisphere and December-February for the southern hemisphere

a $0.8^{\circ} \mathrm{C}$ range and features a significant positive trend since 1980 [18]. This appears to have led to a revival of regional monsoons in the recent few decades, which we explore in more detail next.

Several studies have suggested that, since the 1950s, rainfall associated with the South Asian summer monsoon has decreased [87, 88]. The reduction has been associated with a weakening of the land-ocean thermal contrast driven by relatively enhanced warming of the Indian Ocean in response to greenhouse gases [89, 90], and the effect of anthropogenic aerosols [91-93], and land-cover changes [94]. A recent study reported a reversal of the rainfall trends concurrently with the land-ocean thermal gradient since the early 2000s, which also coincided with suppressed Indian Ocean warming [95]. As discussed by Walker et al. (2015) [10]; however, this declining trend is not robust across regions and datasets and might be more indicative of local changes than changes in the large-scale monsoon.

The East Asian monsoon has exhibited a significant weakening trend in precipitation and circulation [96] from 1954 to 2010. However, instrumental records since 1901 indicate decadal variations but the long-term trend is absent [97, 98]. A number of mechanisms have been proposed to explain the declining trend in rainfall since the 1950s, including variations in snow cover over the Tibetan Plateau [99], variability in both tropical and mid-latitude circulations [96], and variations in tropical Indian and Pacific Ocean SSTs [100]. Analysis of CMIP5 individual forcing experiments indicate a large contribution from aerosol forcing in the second half of the twentieth century [101] for which additional evidence has recently been provided [102].

In Africa, Sahel rainfall over the twentieth century was characterized by marked multi-decadal variability. The 1950s and 1960s were wetter than the century-scale mean, and were followed by the decades of persistent drought of the 1970s and 1980s. Since then, rainfall has partially "recovered" [103]. Spatial and temporal features of this observed recovery resemble patterns of long-term change in model projections [104, 105]: an increase in precipitation in the interior of the Sahel, east of $5^{\circ} \mathrm{W}$, and a shift in seasonality, with a decrease in rainfall in the early season, and an increase in the late season.

As much as past wet and dry periods were characterized by year-to-year persistence, conditions during the current recovery are characterized by year-to-year variability. The 
recovery is consistent with a reduction in North Atlantic aerosol loadings, which by cooling local SSTs relative to the global tropical mean were responsible for drought [77, 106, 107]. CMIP5 simulations are in better agreement than prior assessments that greenhouse gas-induced warming may result in a wetter monsoon, broadly consistent with the current recovery. This can be interpreted to occur when the "upped ante" in increased vertical stability that results from the global ocean-mediated warming is met by increased moisture supply from the local, North Atlantic Ocean. A positive oceanic feedback is consistent with paleoclimate modeling [14]. The extent to which the significant year-toyear variability that has characterized Sahel rainfall since the mid-1990s is a manifestation of internal variability superimposed on an emergent wetting trend remains to be ascertained.

Observations to date show weak or nonexistent trends [82] over the North American Monsoon region due to the presence of large-amplitude decadal variations [108]. Despite increases in the land-sea contrast from 1979 to 2004, [109] found small negative trends in summer precipitation (June-August) over the region in reanalysis datasets, but no such trends in land-based observations over the period 1979-2004. Similarly, Petrie et al. (2014) [110] show no change in precipitation over the northern Chihuahuan Desert over the past century. There is some spatial variability in trends, with precipitation increases over June through September in northwest Mexico and the southwestern USA from 1948 to 2010, with decreases occurring in central and southern Mexico over the same time period [111]. The reduced precipitation could be linked to antecedent wildfire aerosols [112].

Our understanding of South American monsoon trends is limited by intermittent and sparse observations, particularly in the Amazon. Analysis of available data since 1950 suggest an increasing precipitation trend in the southeast [113], with increasing drought in the region of the South Atlantic convergence zone (SACZ), which implies a poleward shift [114]. There is more confidence in observed trends of increasing precipitation extremes in southern and southeastern Brazil and La Plata River Basin, which lends support for the intensification of the monsoon poleward of $20^{\circ} \mathrm{S}[113,115]$. The increasing trend in this region of southeastern South America has been attributed to Antarctic ozone loss and greenhouse warming, both acting to shift the Hadley cell and southern hemisphere jets poleward [116]. Further, there is evidence for a longer monsoon season, with early onsets and late demises for 1979-2010 [115].

The South American monsoon response to ENSO and decadal Pacific and Atlantic SST variations involves a north-south shift in the SACZ that results in a dipole in precipitation [114]. Arias et al. [117] and Fernandes et al.
[118] found evidence for decadal variability with dry (19481970 and 1991-2005) and wet regimes (1971-1990 and 2005-2009). These modes of internal variability can, for a time, mask the regional response to external forcings. This can be seen, for example, in Fig. 3, wherein the model ensemble mean shows precipitation decreases in past decades in response to aerosol forcing before exhibiting precipitation increases as the greenhouse gas forcing begins to dominate the signal.

Let's summarize this discussion of recent trends as they relate to paleomonsoon responses. First, while cooling in the northern hemisphere due to aerosols was a dominant factor from the 1950s to 1980s, asymmetric warming in the northern hemisphere is emerging in the recent period as a result of greenhouse gas forcing [18]. Given this context, observations of precipitation declines in the earlier period followed by recent increases, particularly in the northern hemisphere African and Asian monsoon systems are consistent with expectations [96, 98, 103]. The weak signals seen in the American monsoons are likely due to the dominant influence of internal decadal variations over external forcing [108, 114].

\section{Future of Monsoons in a Warming World}

Anthropogenic greenhouse gases emissions are expected to be the dominant external forcings on climate through the next 100 years. In addition to the competing thermodynamic (increasing atmospheric humidity) and dynamic (slowing of the tropical overturning) responses, as anthropogenic aerosol loadings continue to decrease the asymmetric warming of the northern hemisphere is likely to continue. Uncertainties in this evolution include internal variations on interannual and decadal timescales (Fig. 3), and regional cooling in response to a slowing of the oceanic Atlantic meridional overturning circulation. Although there is some correspondence between inter-hemispheric temperature gradients and shifts in tropical rainfall, a stronger anticorrelation has been shown between ITCZ shifts and crossequatorial energy fluxes which can respond to remote factors.

Climate projections of the global monsoon precipitation indices point to future increases in global monsoon area (i.e., monsoon expansion), precipitation and intensity, largely in response to higher atmospheric humidity (thermodynamic) rather than circulation (dynamic) changes $[119,120]$. It is surprising that northern monsoons' future response is shown to be weaker than in simulations of the mid-Holocene given that the future warming is larger [74]. This result is attributed to differing mechanisms: during the mid-Holocene both thermodynamic and dynamic 
responses act in concert and cross-equatorial energy fluxes shift the ITCZ towards the warmer northern hemisphere; in the future, the dynamic response (weakened tropical circulation) acts against the thermodynamic response with a small net energy flux.

Given the recent findings, rainfall increases are projected for northern hemisphere monsoons due to atmospheric moistening, and in part to asymmetry in warming, which more than compensate for the stabilization of the tropical troposphere as warming proceeds [121], while smaller increases are seen in the southern monsoons. Projections of the length of the monsoon season appear to be mixed, but model sensitivity studies corroborate a remarkable model agreement regarding increased amplitude of the annual cycle of precipitation in the tropics, as well as a phase delay (later start and later end) to warm season rains [122]. In addition to these globally coherent responses, regional differences occur in projections, as are summarized in Table 2 and discussed in the following for the Asian, African, and American monsoons.

CMIP5 projections of the Asian monsoon indicate increased precipitation during summer in South Asia and East Asia as well as Australia [123]. The increasing inter-hemispheric gradient (warmer in the north) leads to larger increases in precipitation in South and East Asia compared to the Australian monsoon [123]. For South Asia, further analysis suggests a poleward shift in the moisturebearing monsoon low-level jet [124]. High-resolution model projections point to weakening and poleward shift in the genesis distribution of monsoon low pressure systems which implies an increased frequency of extreme precipitation events over northern India [125]. Uncertainty in the CMIP5 model projection of South Asian monsoon rainfall has been related to the pattern of SST changes across the western Pacific and Indian Ocean [126].

For the African monsoon, [105] shows greater agreement among CMIP5 models (than was seen in the previous model intercomparison [127]) in the projection of a wetter monsoon overall, and this is reaffirmed by [74]. Despite the particular sensitivity to choice of convection parameterization seen in Sahel rainfall changes [128] (e.g. the Community Earth System Model (CESM) large ensemble in Fig. 3 shows little change in precipitation at the end of the twenty-first century), a wetter future outcome is consistent with understanding the role of external forcing explored in this review. Specifically, it is consistent with the hypothesis that while greenhouse gas-induced warming contributed to the recent drought, it was not warming per se that dried the Sahel. Rather, it was the absence of warming of the North Atlantic relative to the global tropical oceans that caused the drought [106]. Since the absence of North Atlantic warming is largely attributable to anthropogenic aerosols, the reduction in their loading [129] is consistent with the recovery of the rains, and with projections for wetter conditions.

Over the North American monsoon region, the model projections agree that early season monsoon precipitation will decrease while late rainy season precipitation in September and October will increase, with little change in total warm season precipitation [130, 131] despite increases in land-sea contrasts in the models and warming overall [109]. These model projections are at odds with the monsoon expansion during paleoclimatic periods such as the mid-Holocene maximum when radiative forcing intensified. The difference between paleoperiods and future projections may be even larger, as model biases in sea surface temperatures, particularly over the Atlantic Ocean, appear to have long-ranging effects on the future projections [8]. When these SST biases are corrected in high-resolution simulations performed with double $\mathrm{CO}_{2}$, decreases in monsoon precipitation occur from July to October (i.e., even in the late season), with the largest decreases in July and August [8]. These decreases in precipitation are linked to overall increases in atmospheric stability arising from increases in SSTs (the "remote" mechanism discussed by [132-134]).

In contrast with northern hemisphere, during the midHolocene, the monsoons were weaker in the southern hemisphere in response to decreased summer insolation [76]. In the twenty-first century, however, radiative forcing increases in both hemispheres. Consequently, projections show a wetter and longer (both early onset and late withdrawal) South American Monsoon [135], consistent with the idea that the monsoon precipitation should increase in a warmer world. The trends are consistent with the longer monsoon season shown in observations [135]. The monsoon is also projected to expand poleward with diminished early season precipitation and enhanced late season precipitation [115], similar to the North American monsoon without the SST correction applied by [8]; however, the ozone recovery will act in opposition to warming and could lessen the response in this region [116].

\section{Summary}

Although there is no perfect analog to the seasonality and hemispheric asymmetry in the warming response expected in the coming decades, the mid-Holocene and Eemian provide estimates of monsoon response to changes in the inter-hemispheric gradients and cross-equatorial energy fluxes set by orbital variations. Lines of evidence from paleoclimatic proxies and from modeling concur that the African and Asian monsoons are generally wetter and southern hemisphere monsoons are drier [15, 59, 71]. Rainfall in northern monsoons increased during strong 
precession maxima (mid-Holocene and early Eemian). While this would suggest a similar response of northern hemisphere monsoons with increased greenhouse warming, the different patterns of anomalous net energy input especially over land and differing impacts on stability might make these climates not precise analogues of future warming (e.g., [74]). Estimates of reduced rainfall in southern monsoons during mid-Holocene may be less appropriate for the future because greenhouse gas forcing is warming the southern hemisphere and its oceans, even if not at the same rate as north of the equator. $\mathrm{CO}_{2}$ also causes a direct increase in dry static stability, with corresponding circulation changes in both hemispheres [136]. It is also worth restating the difference in the regional ocean feedbacks to the monsoon response in Africa and South Asia [72].

The twentieth century declines in Asian (South and East) and African monsoon rainfall are inconsistent with theory and evidence from paleoclimatic proxies which indicate increasing monsoon precipitation in a warmer climate. Although an array of potential drivers of the observed declines have been proposed for each monsoon region, there is strong evidence that anthropogenic aerosols were a dominant factor in the persistent Sahel drought [77, 83, $84,106]$. There is mounting evidence that aerosols have been a significant driver in South and East Asia as well [83, 84, 91-93, 101, 102]. The compensating influence of aerosol forcing has diminished, with rainfall recoveries occurring in Africa and South Asia, and this forcing is expected to decline in the coming decades due to policy interventions. Thus, the radiative forcing from greenhouse gases is expected to be dominant through much of the twenty-first century.

Mohtadi et al. [2] conclude that total monsoon precipitation in the northern and southern hemispheres will change in opposite directions in the coming decades, owing to differences in hemispheric warming. Given the vertically integrated moist static energy framework that describe shifts in tropical rainbelts, the increasing inter-hemispheric temperature gradient has been associated with a northward ITCZ shift in the zonal mean. How this ITCZ response will manifest in precipitation shifts in different monsoon regions remains an open question in the literature. Climate model projections indicate overall expansion of, but weakened monsoon circulations and increased precipitation in both hemispheres. While more work is need to incorporate the complexities of different monsoon systems, the atmospheric energy budget might provide a basis for a consistent understanding of the role of each of these changes (e.g., stability, lateral import of moist static energy, inter-hemispheric temperature gradients).

As with many other open questions in climate science, our understanding of monsoon circulations remains limited (note, for example, significant model biases in Fig. 3) because of the complexity of these systems, which involve interplays between the large-scale tropical circulation and convection, the influence of both local and remote forcing, interactions between land, atmosphere and ocean, and other components of the climate system [137]. The framework as currently defined (Fig. 2) appears to represent reasonably well the monsoons of Asia and Africa, but will require refinement for monsoons that do not include crossequatorial circulations such as North America. Forward progress requires the use of model hierarchies, which allow for the development and testing of physically driven hypotheses by introducing complexity in a progressive way $[138,139]$. For a problem as complex as that of the monsoon, this needs to include model setups spanning from zonally symmetric aquaplanets with idealized physics [140] to idealized representations of land masses or other zonal asymmetric in both idealized and full physics global climate models $[64,141,142]$ or of the interaction with the ocean circulation [143-145]. The physical constraints and testable ideas emerging from this approach can hence be used to interpret paleorecords, to evaluate comprehensive Earth system models, and to better constrain their past reconstructions and future projections.

Acknowledgements We thank the editor, Robin Chadwick, and two anonymous reviewers for constructive critiques that have shaped the structure and improved the clarity of this review. Conversations with Michela Biasutti were essential in the development of this review. We acknowledge the CESM Large Ensemble Community Project and supercomputing resources provided by NSF/CISL/Yellowstone. CMAP and GPCP precipitation data is provided by the NOAA/OAR/ESRL PSD, Boulder, Colorado, USA, and acquired from their Web site at https://www.esrl.noaa.gov/psd/.

Funding Information The authors acknowledge grant support as follows: A.S. acknowledges NSF support from CAREER-1056216, S.B. acknowledges support by NSF under award AGS-1462544, S.J.C. acknowledges NOAA support from awards NA15OAR43100095, NA16OAR4310079, NA18OAR4310277, S.A.R. acknowledges support from the University of Delaware Research Foundation from award GEOG45212717000, and M.R. acknowledges Fondecyt 1171773, Nucleo Milenio PaleoClimate and FONDAP/ CONICYT 15110009.

\section{Compliance with Ethical Standards}

Conflict of interest The authors declare they have no conflicts of interest.

\section{References}

1. Trenberth KE, Stepaniak DP, Caron JM. The global monsoon as seen through the divergent atmospheric circulation. J. Climate. 2000;13(22):3969-3993. https://doi.org/10.1175/15200442(2000)013〈3969:TGMAST〉2.0.CO;2. 
2. Mohtadi M, Prange M, Steinke S. Palaeoclimatic insights into forcing and response of monsoon rainfall. Nature. 2016;533: 191-199. https://doi.org/10.1038/nature17450.

3. Wang P, Wang B, Cheng H, Fasullo J, Guo Z, Kiefer T, Liu Z. The global monsoon across time scales: mechanisms and outstanding issues. Earth-Science Rev. 2017;174:84-121. https:// doi.org/10.1016/j.earscirev.2017.07.006.

4. Biasutti M, Voigt A, Boos WR, Braconnot P, Hargreaves JC, Harrison SP, Kang SM, Mapes BE, Scheff J, Schumacher C, Sobel AH, Xie SP. Global energetics and local physics as drivers of past, present and future monsoons. Nat. Geosci. 2018;11(6): 392-400. https://doi.org/10.1038/s41561-018-0137-1.

5. Schneider T, Bischoff T, Haug GH. Migrations and dynamics of the intertropical convergence zone. Nature. 2014;513:45-53. https://doi.org/10.1038/nature13636.

6. Emanuel KA. On thermally direct circulations in moist atmospheres. J. Atmos. Sci. 1995;52(9):1529-1534.

7. Privé N. C., Plumb RA. Monsoon dynamics with interactive forcing. Part II: impact of eddies and asymmetric geometries. J. Atmos. Sci. 2007;64(5):1431-1442.

8. Pascale S, Boos WR, Bordoni S, Delworth TL, Kapnick SB, Murakami H, Vecchi GA, Zhang W. Weakening of the North American monsoon with global warming. Nat. Clim. Change. 2017;7:806-812. https://doi.org/10.1038/nclimate3412.

9. Hurley JV, Boos WR. Interannual variability of monsoon precipitation and local subcloud equivalent potential temperature. J. Climate. 2013;26(23):9507-9527. https://doi.org/10.1175/JCLID-12-00229.1.

10. Walker JM, Bordoni S, Schneider T. Interannual variability in the large-scale dynamics of the South Asian summer monsoon. J Climate. 2015;28(9):3731-3750. https://doi.org/10.1175/JCLID-14-00612.1.

11. Kang SM, Held IM, Frierson DMW, Zhao M. The response of the ITCZ to extratropical thermal forcing: idealized slab-ocean experiments with a GCM. J. Climate. 2008;21(14):3521-3532. https://doi.org/10.1175/2007JCLI2146.1.

12. Kang SM, Frierson DMW, Held IM. The tropical response to extratropical thermal forcing in an idealized GCM: the importance of radiative feedbacks and convective parameterization. J. Atmos. Sci. 2009;66(9):2812-2827. https://doi.org/10.1175/ 2009JAS2924.1.

13. Frierson DMW, Hwang YT. Extratropical influence on ITCZ shifts in slab ocean simulations of global warming. J. Climate. 2011;25(2):720-733. https://doi.org/10.1175/JCLI-D-11-00116.1.

14. Braconnot P, Marzin C, Grégoire L., Mosquet E, Marti O. Monsoon response to changes in Earth's orbital parameters: comparisons between simulations of the Eemian and of the Holocene. Clim. Past. 2008;4(2):459-493. https://doi.org/10.5194/cp-4-2812008.

15. Zhao Y, Harrison SP. Mid-Holocene monsoons: a multi-model analysis of the inter-hemispheric differences in the responses to orbital forcing and ocean feedbacks. Clim. Dyn. 2012;39(6): 1457-1487. https://doi.org/10.1007/s00382-011-1193-z.

16. Chiang JCH, Friedman AR. Extratropical cooling, interhemispheric thermal gradients, and tropical climate change. Annu. Rev. Earth Planet. Sci. 2012;40(1):383-412. https://doi.org/10. 1146/annurev-earth-042711-105545.

17. Taylor KE, Stouffer RJ, Meehl GA. An overview of CMIP5 and the experiment design. Bull. Amer. Meteor. Soc. 2012;93:485498. https://doi.org/10.1175/BAMS-D-11-00094.1.

18. Friedman AR, Hwang YT, Chiang JCH, Frierson DMW. Interhemispheric temperature asymmetry over the twentieth century and in future projections. J. Climate. 2013;26(15):54195433. https://doi.org/10.1175/JCLI-D-12-00525.1.

19. Donohoe A, Marshall J, Ferreira D, Mcgee D. The relationship between ITCZ location and cross-equatorial atmospheric heat transport: from the seasonal cycle to the last glacial maximum. J. Climate. 2012;26(11):3597-3618. https://doi.org/10.1175/JCLID-12-00467.1.

20. Seo J, Kang SM, Merlis TM. A model intercomparison of the tropical precipitation response to a $\mathrm{CO} 2$ doubling in aquaplanet simulations. Geophys. Res. Lett. 2016;44(2):993-1000. https://doi.org/10.1002/2016GL072347.

21. Wei H, Bordoni S. Energetic constraints on the ITCZ position in idealized simulations with a seasonal cycle. J. Adv. Model. Earth Syst. 2018;10:1708-1725. https://doi.org/10.1029/2018MS001313.

22. Singarayer JS, Valdes PJ, Roberts WHG. Ocean dominated expansion and contraction of the late Quaternary tropical rainbelt. Sci. Rep. 2017;7(1):9382. https://doi.org/10.1038/s41598017-09816-8.

23. Roberts WHG, Valdes PJ, Singarayer JS. Can energy fluxes be used to interpret glacial/interglacial precipitation changes in the tropics?. Geophys. Res. Lett. 2017;44(12):6373-6382. https://doi.org/10.1002/2017GL073103.

24. Adam O, Bischoff T, Schneider T. Seasonal and interannual variations of the energy flux equator and ITCZ. Part II: Zonally varying shifts of the ITCZ. J. Climate. 2016;29(20):7281-7293. https://doi.org/10.1175/JCLI-D-15-0710.1.

25. Boos WR, Korty RL. Regional energy budget control of the intertropical convergence zone and application to mid-Holocene rainfall. Nat. Geosci. 2016;9:892-897. https://doi.org/10.1038/ ngeo2833.

26. Zhisheng A, Guoxiong W, Jianping L, Youbin S, Yimin L, Weijian Z, Yanjun C, Anmin D, Li L, Jiangyu M, Hai C, Zhengguo S, Liangcheng T, Hong Y, Hong A, Hong C, Juan F. Global monsoon dynamics and climate change. Annu Rev Earth Planet. Sci. 2015;43(1):29-77. https://doi.org/10.1146/annurevearth-060313-054623.

27. Boos WR, Kuang Z. Dominant control of the South Asian monsoon by orographic insulation versus plateau heating. Nature. 2010;463:218-222. https://doi.org/10.1038/nature08707.

28. Yihui D, Chan JC. The East Asian summer monsoon: an overview. Meteorol. Atmos. Phys. 2005;89(1-4):117-142.

29. Nicholson SE. A revised picture of the structure of the "monsoon" and land ITCZ over West Africa. Clim. Dyn. 2009;32(7-8): $1155-1171$.

30. Douglas MW, Maddox RA, Howard K, Reyes S. The Mexican monsoon. J Climate. 1993;6(8):1665-1677. https://doi. org/10.1175/1520-0442(1993)006〈1665:TMM $>2.0 . C O ; 2$.

31. Adams DK, Comrie AC. The North American monsoon. Bull. Amer. Meteor. Soc. 1997;78(10):2197-2214. https://doi.org/10. 1175/1520-0477(1997)078〈2197:TNAM $\rangle 2.0 . C O ; 2$.

32. Zhou J, Lau KM. Does a monsoon climate exist over South America? J Climate. 1998;11(5):1020-1040. https://doi.org/10. 1175/1520-0442(1998)011〈1020:DAMCEO $2.0 . C O ; 2$.

33. Gan MA, Kousky VE, Ropelewski CF. The South America monsoon circulation and its relationship to rainfall over westcentral Brazil. J. Climate. 2004;17(1):47-66. https://doi.org/10. 1175/1520-0442(2004)017〈0047:TSAMCA $\rangle 2.0 . C O ; 2$.

34. Foster GL, Royer DL, Lunt DJ. Future climate forcing potentially without precedent in the last 420 million years. Nature Comm. 2017;8(14):845.

35. Zhang YG, Pagani M, Liu Z, Bohaty SM, DeConto R. A 40million-year history of atmospheric CO2. Phil. Trans. R. Soc. A. 2013;371(2001):20130,096.

36. Masson-Delmotte V. Coauthors, 2013: Information from paleoclimate archives. In: Climate Change 2013: the physical science basis. Contribution of working group I to the fifth assessment Report of the Intergovernmental Panel on Climate Change, TF Stocker et al. Cambridge: Cambridge University Press; 2013. p. 383-464.

37. Marshall J, Donohoe A, Ferreira D, McGee D. The ocean's role in setting the mean position of the Inter-Tropical Convergence 
Zone. Clim. Dyn. 2014;42(7):1967-1979. https://doi.org/10. 1007/s00382-013-1767-z.

38. Byrne MP, O'Gorman PA. Land-ocean warming contrast over a wide range of climates: convective quasi-equilibrium theory and idealized simulations. J. Climate. 2012;26(12):4000-4016. https://doi.org/10.1175/JCLI-D-12-00262.1.

39. Byrne MP, Schneider T. Narrowing of the itcz in a warming climate: physical mechanisms. Geophys. Res. Lett. 2016;43(21):11,350-11,357. https://doi.org/10.1002/2016GL07 0396.

40. Clemens SC, Murray DW, Prell WL. Nonstationary phase of the Plio-Pleistocene Asian monsoon. Science. 1996;274(5289): 943-948.

41. Liu T, Ding Z. Chinese loess and the paleomonsoon. Ann. Rev. Earth Planet. Sci. 1998;26(1):111-145.

42. Wang P, Clemens S, Beaufort L, Braconnot P, Ganssen G, Jian Z, Kershaw P, Sarnthein M. Evolution and variability of the Asian monsoon system: state of the art and outstanding issues. Quaternary Sci. Rev. 2005;24(5-6):595-629.

43. Dowsett HJ, Robinson MM. Mid-Pliocene equatorial Pacific sea surface temperature reconstruction: a multi-proxy perspective. Philos. T. Roy. Soc. A. 2009;367(1886):109-125.

44. Lawrence KT, Liu Z, Herbert TD. Evolution of the eastern tropical Pacific through Plio-Pleistocene glaciation. Science. 2006;312(5770):79-83.

45. Wara MW, Ravelo AC, Delaney ML. Permanent El Niñolike conditions during the Pliocene warm period. Science. 2005;309(5735):758-761.

46. Haywood A, Hill D, Dolan A, Otto-Bliesner B, Bragg F, Chan WL, Chandler M, Contoux C, Dowsett H, Jost A, et al. Largescale features of Pliocene climate: results from the Pliocene Model Intercomparison Project. Clim. Past. 2013;9(1):191-209.

47. Sun Y, Ramstein G, Contoux C, Zhou T. A comparative study of large-scale atmospheric circulation in the context of a future scenario (RCP4.5) and past warmth (mid-Pliocene). Clim. Past. 2013;9(4):1613-1627. https://doi.org/10.5194/cp-9-16132013.

48. Corvec S, Fletcher CG. Changes to the tropical circulation in the mid-pliocene and their implications for future climate. Clim. Past. 2017;13(2):135-147.

49. Sun Y, Zhou T, Ramstein G, Contoux C, Zhang Z. Drivers and mechanisms for enhanced summer monsoon precipitation over East Asia during the mid-Pliocene in the IPSL-CM5A. Clim Dyn. 2016;46(5):1437-1457. https://doi.org/10.1007/s00382015-2656-4.

50. Zhang R, Jiang D, Zhang Z. Causes of mid-Pliocene strengthened summer and weakened winter monsoons over East Asia. Adv. Atmos. Sci. 2015;32(7):1016-1026.

51. Sun Y, Ramstein G, Li LZX, Contoux C, Tan N, Zhou T. Quantifying East Asian summer monsoon dynamics in the ECP4.5 scenario with reference to the mid-Piacenzian warm period. Geophys Res Lett. 2018;45(22):12,523-12,533. https://doi.org/10.1029/2018GL080061.

52. Burls NJ, Fedorov AV. Simulating Pliocene warmth and a permanent El Niño-like state: the role of cloud albedo. Paleoceanography. 2014;29(10):893-910. https://doi.org/10.1002/ 2014PA002644.

53. He J, Soden BJ. Anthropogenic weakening of the tropical circulation: the relative roles of direct $\mathrm{CO} 2$ forcing and sea surface temperature change. J. Climate. 2015;28(22):8728-8742. https://doi.org/10.1175/JCLI-D-15-0205.1.

54. Ferrett S, Collins M, Ren HL. Diagnosing relationships between mean state biases and El Niño shortwave feedback in CMIP5 models. J. Climate. 2017;31(4):1315-1335. https://doi. org/10.1175/JCLI-D-17-0331.1.
55. Hoffman JS, Clark PU, Parnell AC, He F. Regional and global sea-surface temperatures during the last interglaciation. Science. 2017;355(6322):276-279.

56. Otto-Bliesner BL, Rosenbloom N, Stone EJ, McKay NP, Lunt DJ, Brady EC, Overpeck JT. How warm was the last interglacial? New model-data comparisons. Philos Trans A Math Phys Eng Sci. 2013;371:2001. https://doi.org/10.1098/rsta.2013. 0097.

57. Kathayat G, Cheng H, Sinha A, Spötl C, Edwards RL, Zhang H, Li X, Yi L, Ning Y, Cai Y, et al. Indian monsoon variability on millennial-orbital timescales. Sci. Rep. 2016;6(24):374.

58. Govin A, Varma V, Prange M. Astronomically forced variations in western African rainfall $\left(21^{\circ} \mathrm{N}-20^{\circ} \mathrm{S}\right)$ during the Last Interglacial period. Geophys Res Lett. 2014;41(6):2117-2125.

59. Baker PA, Fritz SC. Nature and causes of Quaternary climate variation of tropical South America. Quat Sci Rev. 2015;124:3147. https://doi.org/10.1016/j.quascirev.2015.06.011.

60. Burns SJ, Kanner LC, Cheng H, Lawrence Edwards R. A tropical speleothem record of glacial inception, the South American Summer Monsoon from 125 to 115 ka. Clim Past. 2015;11(6):931-938.

61. Pedersen RA, Langen PL, Vinther BM. The last interglacial climate: comparing direct and indirect impacts of insolation changes. Clim Dyn. 2017;48(9-10):3391-3407.

62. Gierz P, Werner M, Lohmann G. Simulating climate and stable water isotopes during the Last Interglacial using a coupled climate-isotope model. J Adv Model Earth Sys. 2017;9(5):20272045.

63. Garcin Y, Vincens A, Williamson D, Buchet G, Guiot J. Abrupt resumption of the African Monsoon at the Younger Dryas-Holocene climatic transition. Quat Sci Rev. 2007;26(56):690-704.

64. Shekhar R, Boos WR. Improving energy-based estimates of monsoon location in the presence of proximal deserts. J Climate. 2016;29(13):4741-4761. https://doi.org/10.1175/JCLI-D-15-07 47.1.

65. Wang X, Auler AS, Edwards RL, Cheng H, Ito E, Solheid M. Interhemispheric anti-phasing of rainfall during the last glacial period. Quat Sci Rev. 2006;25(23-24):3391-3403.

66. Kuechler RR, Dupont LM, Schefuay E. Hybrid insolation forcing of Pliocene monsoon dynamics in West Africa. Clim Past. 2018;14(1):73-84. https://doi.org/10.5194/cp-14-73-2018.

67. McGee D, Donohoe A, Marshall J, Ferreira D. Changes in itcz location and cross-equatorial heat transport at the Last Glacial Maximum, Heinrich Stadial 1, and the mid-Holocene. Earth Planet Sci. Lett. 2014;390:69-79.

68. Kageyama M, Merkel U, Otto-Bliesner B, Prange M, AbeOuchi A, Lohmann G, Ohgaito R, Roche D, Singarayer J, Swingedouw D, et al. Climatic impacts of fresh water hosing under last glacial maximum conditions: a multi-model study. Clim Past. 2013;9(2):935-953.

69. Ma J, Xie SP. Regional patterns of sea surface temperature change: a source of uncertainty in future projections of precipitation and atmospheric circulation. J Climate. 2012;26(8):24822501. https://doi.org/10.1175/JCLI-D-12-00283.1.

70. Collins M, Knutti R, Arblaster J, Dufresne JL, Fichefet T, Friedlingstein P, Gao X, Gutowski W, Johns T, Krinner G, Shongwe M, Tebaldi C, Weaver A, Wehner M. Long-term climate change: projections, commitments and irreversibility. In: Climate change 2013: the physical science basis. IPCC Working Group I Contribution to the 5th assessment report of the intergovernmental panel on climate change. Cambridge: Cambridge University Press; 2013.

71. Jiang D, Tian Z, Lang X. Mid-Holocene global monsoon area and precipitation from PMIP simulations. Clim Dyn. 2015;44(9): 2493-2512. https://doi.org/10.1007/s00382-014-2175-8. 
72. Braconnot $\mathrm{P}$, Harrison SP, Kageyama M, Bartlein PJ, MassonDelmotte V, Abe-Ouchi A, Otto-Bliesner B, Zhao Y. Evaluation of climate models using palaeoclimatic data. Nat Clim Change. 2012;2:417-424. https://doi.org/10.1038/nclimate1456.

73. Harrison SP, Bartlein PJ, Izumi K, Li G, Annan J, Hargreaves J, Braconnot P, Kageyama M. Evaluation of CMIP5 palaeosimulations to improve climate projections. Nat Clim Change. 2015;5:735-743. https://doi.org/10.1038/nclimate2649.

74. D’Agostino R, Bader J, Bordoni S, Ferreira D, Jungclaus J. Northern Hemisphere monsoon response to mid-Holocene orbital forcing and greenhouse gas-induces global warming. Geophys Res Lett. 2019. In press.

75. Metcalfe SE, Barron JA, Davies SJ. The Holocene history of the North American monsoon: "known knowns" and "known unknowns" in understanding its spatial and temporal complexity. Quat Sci Rev. 2015;120:1-27. https://doi.org/10.1016/j.quasci rev.2015.04.004.

76. Prado LF, Wainer I, Chiessi CM. Mid-Holocene PMIP3/CMIP5 model results: intercomparison for the South American monsoon system. Holocene. 2013;23(12):1915-1920. https://doi.org/10.1177/0959683613505336.

77. Booth BBB, Dunstone NJ, Halloran PR, Andrews T, Bellouin N. Aerosols implicated as a prime driver of twentieth-century North Atlantic climate variability. Nature. 2012;484:228-232. https://doi.org/10.1038/nature10946.

78. Clement A, Bellomo K, Murphy LN, Cane MA, Mauritsen T, Rädel G, Stevens B. The Atlantic Multidecadal Oscillation without a role for ocean circulation. Science. 2015;350(6258):320.

79. Wang B, Ding Q. Changes in global monsoon precipitation over the past 56 years. Geophys Res Lett. 2006;33:6. https://doi.org/10.1029/2005GL025347.

80. Hsu PC, Li T, Wang B. Trends in global monsoon area and precipitation over the past 30 years. Geophys Res Lett. 2011;38(8):L08,701. https://doi.org/10.1029/2011GL046893.

81. Lin R, Zhou T, Qian Y. Evaluation of global monsoon precipitation changes based on five reanalysis datasets. J Climate. 2013;27(3):1271-1289. https://doi.org/10.1175/JCLI-D-13-002 15.1.

82. Zhou T, Zhang L, Li H. Changes in global land monsoon area and total rainfall accumulation over the last half century. Geophys Res Lett 35(16). 2008.

83. Polson D, Bollasina M, Hegerl GC, Wilcox LJ. Decreased monsoon precipitation in the Northern Hemisphere due to anthropogenic aerosols. Geophys Res Lett. 2014;41(16):60236029. https://doi.org/10.1002/2014GL060811.

84. Ackerley D, Booth BBB, Knight SHE, Highwood EJ, Frame DJ, Allen MR, Rowell DP. Sensitivity of twentiethcentury Sahel rainfall to sulfate aerosol and $\mathrm{CO}_{2}$ forcing. $\mathrm{J}$ Climate. 2011;24(19):4999-5014. https://doi.org/10.1175/JCLID-11-00019.1.

85. Kang SM, Held IM. Tropical precipitation, SSTs and the surface energy budget: a zonally symmetric perspective. Clim Dyn. 2012; 38(9):1917-1924. https://doi.org/10.1007/s00382-011-1048-7.

86. Bischoff T, Schneider T. Energetic constraints on the position of the Intertropical Convergence Zone. J Climate. 2014;27(13): 4937-4951. https://doi.org/10.1175/JCLI-D-13-00650.1.

87. Ramanathan V, Chung C, Kim D, Bettge T, Buja L, Kiehl JT, Washington WM, Fu Q, Sikka DR, Wild M. Atmospheric brown clouds: impacts on South Asian climate and hydrological cycle. Proc Natl Acad Sci. 2005;102(15):5326. https://doi.org/10.1073/pnas.0500656102.

88. Singh D, Tsiang M, Rajaratnam B, Diffenbaugh NS. Observed changes in extreme wet and dry spells during the South Asian summer monsoon season. Nat Clim Change. 2014;4:456-461. https://doi.org/10.1038/nclimate2208.
89. Chung CE, Ramanathan V. Weakening of North Indian SST gradients and the monsoon rainfall in India and the Sahel. J Climate. 2006;19(10):2036-2045. https://doi.org/10.1175/JCLI38 20.1.

90. Roxy MK, Ritika K, Terray P, Murtugudde R, Ashok K, Goswami BN. Drying of Indian subcontinent by rapid Indian Ocean warming and a weakening land-sea thermal gradient. Nat Commun. 2015;6:7423. https://doi.org/10.1038/ncomms8423.

91. Bollasina MA, Ming Y, Ramaswamy V. Anthropogenic aerosols and the weakening of the South Asian summer monsoon. Science. 2011;334(6055):502. https://doi.org/10.1126/science.1204994.

92. Salzmann M, Weser H, Cherian R. Robust response of Asian summer monsoon to anthropogenic aerosols in CMIP5 models. J Geophys Res Atmos. 2014;119(19):11,321-11,337. https://doi. org/10.1002/2014JD021783.

93. Guo L, Turner AG, Highwood EJ. Impacts of 20th century aerosol emissions on the South Asian monsoon in the CMIP5 models. Atmos Chem Phys. 2015;15(11):6367-6378. https://doi.org/10. 5194/acp-15-6367-2015.

94. Paul S, Ghosh S, Oglesby R, Pathak A, Chandrasekharan A, Ramsankaran R. Weakening of Indian summer monsoon rainfall due to changes in land use land cover. Sci Rep. 2016;6:32,177. https://doi.org/10.1038/srep32177.

95. Jin Q, Wang C. A revival of Indian summer monsoon rainfall since 2002. Nat Clim Change. 2017;7:587-594. https://doi.org/ 10.1038/nclimate3348.

96. Zhu C, Wang B, Qian W, Zhang B. Recent weakening of northern East Asian summer monsoon: a possible response to global warming. Geophys Res Lett 39(9). 2012.

97. Zhou T, Gong D, Li J, Li B. Detecting and understanding the multi-decadal variability of the East Asian Summer Monsoonrecent progress and state of affairs. Meteorol Z. 2009;18(4): 455-467.

98. Zhang L, Zhou T. An assessment of monsoon precipitation changes during 1901-2001. Clim Dyn. 2011;37(1-2):279-296.

99. Ding Y, Sun Y, Wang Z, Zhu Y, Song Y. Inter-decadal variation of the summer precipitation in China and its association with decreasing Asian summer monsoon Part II: Possible causes. Int J Climatol. 2009;29(13):1926-1944. https://doi.org/10.1002/ joc. 1759.

100. Qian C, Zhou T. Multidecadal variability of North China aridity and its relationship to PDO during 1900-2010. J Climate. 2013;27(3):1210-1222. https://doi.org/10.1175/JCLI-D-13-002 35.1 .

101. Song F, Zhou T, Qian Y. Responses of East Asian summer monsoon to natural and anthropogenic forcings in the 17 latest CMIP5 models. Geophys Res Lett. 2014;41(2):596-603. https://doi.org/10.1002/2013GL058705.

102. Li Z, Lau WKM, Ramanathan V, Wu G, Ding Y, Manoj MG, Liu J, Qian Y, Li J, Zhou T, Fan J, Rosenfeld D, Ming Y, Wang Y, Huang J, Wang B, Xu X, Lee SS, Cribb M, Zhang F, Yang X, Zhao C, Takemura T, Wang K, Xia X, Yin Y, Zhang H, Guo J, Zhai PM, Sugimoto N, Babu SS, Brasseur GP. Aerosol and monsoon climate interactions over Asia. Rev Geophys. 2016;54(4):866-929. https://doi.org/10.1002/ 2015RG000500.

103. Nicholson S. On the question of the "recovery" of the rains in the West African Sahel. J Arid Environ. 2005;63(3):615-641. https://doi.org/10.1016/j.jaridenv.2005.03.004.

104. Biasutti M, Sobel AH. Delayed Sahel rainfall and global seasonal cycle in a warmer climate. Geophys Res Lett. 2009;36:23. https://doi.org/10.1029/2009GL041303.

105. Biasutti M. Forced Sahel rainfall trends in the CMIP5 archive. J Geophys Res Atmos. 2013;118(4):1613-1623. https://doi.org/ 10.1002/jgrd.50206. 
106. Giannini A, Salack S, Lodoun T, Ali A, Gaye AT, Ndiaye O. A unifying view of climate change in the Sahel linking intra-seasonal, interannual and longer time scales. Env Res Lett. 2013;8(2):024,010. https://doi.org/10.1088/1748-9326/8/2/024 010 .

107. Wang H, Xie S, Tokinaga H, Liu Q, Kosaka Y. Detecting cross-equatorial wind change as a fingerprint of climate response to anthropogenic aerosol forcing. Geophys Res Lett. 2016;43(7):3444-3450. https://doi.org/10.1002/2016GL068521.

108. Seager R, Vecchi GA. Greenhouse warming and the 21 st century hydroclimate of southwestern North America. Proc Natl Acad Sci. 2010;107(50):21,277-21,282.

109. Torres-Alavez A, Cavazos T, Turrent C. Land-sea thermal contrast and intensity of the North American monsoon under climate change conditions. J Climate. 2014;27(12):4566-4580. https://doi.org/10.1175/JCLI-D-13-00557.1.

110. Petrie MD, Collins SL, Gutzler DS, Moore DM. Regional trends and local variability in monsoon precipitation in the northern Chihuahuan desert. USA J Arid Env. 2014;103:63-70. https://doi.org/10.1016/j.jaridenv.2014.01.005.

111. Hoell A, Funk C, Barlow M, Shukla S. Recent and possible future variations in the North American monsoon. The Monsoons and Climate Change: observations and modeling. In: de Carvalho $\mathrm{L}$ and Jones C, editors. Springer International Publishing; 2016. p. 149-162, https://doi.org/10.1007/978-3-319-21650-8_7.

112. McKendry IG, Gutzler DS. A possible link between wildfire aerosol and North American Monsoon precipitation in Arizona-New Mexico. Int J Climatol. 2014;35(10):3178-3184. https://doi.org/10.1002/joc.4195.

113. Skansi MDLM, Brunet M, Sigró J, Aguilar E, Arevalo Groening JA, Bentancur OJ, Castellón Geier Y. R, Correa Amaya RL, Jácome H, Malheiros Ramos A, Oria Rojas C, Pasten AM, Sallons Mitro S, Villaroel Jiménez C, Martínez $\mathrm{R}$, Alexander LV, Jones PD. Warming and wetting signals emerging from analysis of changes in climate extreme indices over South America. Global Planet Change. 2013;100:295-307. https://doi.org/10.1016/j.gloplacha.2012.11.004.

114. Grimm AM, Saboia JPJ. Interdecadal variability of the South American precipitation in the monsoon season. J Climate. 2014;28(2):755-775. https://doi.org/10.1175/JCLI-D-14-00046.1.

115. de Carvalho LMV, Cavalcanti IFA. The South American monsoon system (SAMS). The monsoons and climate change: observations and modeling. In: de Carvalho LMV and Jones C, editors. Cham: Springer International Publishing; 2016. p. 121-148, https://doi.org/10.1007/978-3-319-21650-8_6.

116. Gonzalez PL, Polvani LM, Seager R, Correa GJ. Stratospheric ozone depletion: a key driver of recent precipitation trends in South Eastern South America. Clim Dyn. 2014;42(7-8):17751792.

117. Arias PA, Fu R, Mo KC. Decadal variation of rainfall seasonality in the North American monsoon region and its potential causes. J Climate. 2012;25(12):4258-4274. https://doi.org/10. 1175/JCLI-D-11-00140.1.

118. Fernandes K, Giannini A, Verchot L, Baethgen W, Pinedo-Vasquez M. Decadal covariability of Atlantic SSTs and western Amazon dry-season hydroclimate in observations and CMIP5 simulations. Geophys Res Lett. 2015;42(16):6793-6801. https://doi.org/10.1002/2015GL063911.

119. Hsu PC, Li T, Murakami H, Kitoh A. Future change of the global monsoon revealed from 19 CMIP5 models. J Geophys Res Atmos. 2013;118(3):1247-1260. https://doi.org/10.1002/jgrd. 50145 .

120. Kitoh A, Endo H, Krishna Kumar K, Cavalcanti IFA, Goswami $\mathrm{P}$, Zhou T. Monsoons in a changing world: a regional perspective in a global context. J Geophys Res Atmos. 2013;118(8):30533065. https://doi.org/10.1002/jgrd.50258.

121. Lee JY, Wang B. Future change of global monsoon in the CMIP5. Clim Dyn. 2014;42(1):101-119. https://doi.org/10.1007/ s00382-012-1564-0.

122. Dwyer JG, Biasutti M, Sobel AH. The effect of greenhouse gas-induced changes in SST on the annual cycle of zonal mean tropical precipitation. J Climate. 2014;27(12):4544-4565. https://doi.org/10.1175/JCLI-D-13-00216.1.

123. Wang B, Yim SY, Lee JY, Liu J, Ha KJ. Future change of Asian-Australian monsoon under RCP4.5 anthropogenic warming scenario. Clim Dyn. 2014;42(1):83-100. https://doi.org/10. 1007/s00382-013-1769-x.

124. Sandeep S, Ajayamohan RS. Poleward shift in Indian summer monsoon low level jetstream under global warming. Clim Dyn. 2015;45(1):337-351. https://doi.org/10.1007/s00382-014-2261-y.

125. Sandeep S, Ajayamohan RS, Boos WR, Sabin TP, Praveen V. Decline and poleward shift in Indian summer monsoon synoptic activity in a warming climate. Proc Natl Acad Sci. 2018;115(11):2681. https://doi.org/10.1073/pnas.1709031115.

126. Chen X, Zhou T. Distinct effects of global mean warming and regional sea surface warming pattern on projected uncertainty in the South Asian summer monsoon. Geophys Res Lett. 2015;42(21):9433-9439.

127. Meehl G, Covey C, Delworth T, Latif M, McAvaney B, Mitchell J, Stouffer R, Taylor K. The WCRPCMIP3 multimodel dataset: a new era in climate change research. Bull Amer Meteor Soc. 2007;88:1383-1394. https://doi.org/10.1175/BAMS-88-91383.

128. Hill SA, Ming Y, Held IM, Zhao M. A moist static energy budget-based analysis of the Sahel rainfall response to uniform oceanic warming. J Climate. 2017;30(15):5637-5660. https://doi.org/10.1175/JCLI-D-16-0785.1.

129. Chang CY, Chiang JCH, Wehner MF, Friedman AR, Ruedy R. Sulfate aerosol control of tropical Atlantic climate over the twentieth century. J Climate. 2010;24(10):2540-2555. https://doi.org/10.1175/2010JCLI4065.1.

130. Cook BI, Seager R. The response of the North American monsoon to increased greenhouse gas forcing. J Geophys Res Atmos. 2013;118(4):1690-1699. https://doi.org/10.1002/jgrd.50111.

131. Maloney ED, Camargo SJ, Chang E, Colle B, Fu R, Geil KL, Hu Q, Jiang X, Johnson N, Karnauskas KB, Kinter J, Kirtman B, Kumar S, Langenbrunner B, Lombardo K, Long LN, Mariotti A, Meyerson JE, Mo KC, Neelin JD, Pan Z, Seager R, Serra Y, Seth A, Sheffield J, Stroeve J, Thibeault J, Xie SP, Wang C, Wyman B, Zhao M. North American climate in CMIP5 experiments: Part III: Assessment of twenty-first-century projections. J Climate. 2013;27(6):22302270. https://doi.org/10.1175/JCLI-D-13-00273.1.

132. Giannini A. Mechanisms of climate change in the semiarid African Sahel: the local view. J Climate. 2010;23(3):743-756. https://doi.org/10.1175/2009JCLI3123.1.

133. Seth A, Rauscher SA, Rojas M, Giannini A, Camargo SJ. Enhanced spring convective barrier for monsoons in a warmer world Clim Chang. 2011;104(2):403-414. https://doi.org/10. 1007/s10584-010-9973-8.

134. Seth A, Rauscher SA, Biasutti M, Giannini A, Camargo SJ, Rojas M. CMIP5 projected changes in the annual cycle of precipitation in monsoon regions. J Climate. 2013;26(19):73287351. https://doi.org/10.1175/JCLI-D-12-00726.1.

135. Jones C, Carvalho LMV. Climate change in the South American monsoon system: present climate and CMIP5 projections. J Climate. 2013;26(17):6660-6678. https://doi.org/10.1175/JCLID-12-00412.1. 
136. Bony S, Bellon G, Klocke D, Sherwood S, Fermepin S, Denvil S. Robust direct effect of carbon dioxide on tropical circulation and regional precipitation. Nat Geosci. 2013;6:447451. https://doi.org/10.1038/ngeo1799.

137. Bony S, Stevens B, Frierson DMW, Jakob C, Kageyama M, Pincus R, Shepherd TG, Sherwood SC, Siebesma AP, Sobel $\mathrm{AH}$, Watanabe M, Webb MJ. Clouds, circulation and climate sensitivity. Nat Geosci. 2015;8:261-268. https://doi.org/10.10 38/ngeo2398;

138. Collins M, Minobe S, Barreiro M, Bordoni S, Kaspi Y, Kuwano-Yoshida A, Keenlyside N, Manzini E, O'Reilly CH, Sutton R, Xie SP, Zolina O. Challenges and opportunities for improved understanding of regional climate dynamics. Nat Clim Change. 2018;8(2):101-108. https://doi.org/10.1038/s41558-0170059-8.

139. Jeevanjee N, Hassanzadeh P, Hill S, Sheshadri A. A perspective on climate model hierarchies. J Adv Model Earth Syst. 2017;9(4):1760-1771. https://doi.org/10.1002/2017MS001038.

140. Faulk S, Mitchell J, Bordoni S. Effects of rotation rate and seasonal forcing on the ITCZ extent in planetary atmospheres. J Atmos Sci. 2016;74(3):665-678. https://doi.org/10.1175/JASD-16-0014.1.

141. Voigt A, Biasutti M, Scheff J, Bader J, Bordoni S, Codron F, Dixon RD, Jonas J, Kang SM, Klingaman NP, Leung R, Lu J, Mapes B, Maroon EA, McDermid S, Park JY, Roehrig R, Rose BEJ, Russell GL, Seo J, Toniazzo T, Wei HH, Yoshimori M. Vargas Zeppetello, L.R.: The tropical rain belts with an annual cycle and a continent model intercomparison project: TRACMIP. J Adv Model Earth Syst. 2016;8(4):18681891. https://doi.org/10.1002/2016MS000748.

142. Levine XJ, Boos WR. A mechanism for the response of the zonally asymmetric subtropical hydrologic cycle to global warming. J Climate. 2016;29(21):7851-7867. https://doi.org/10.1175/ JCLI-D-15-0826.1.

143. Schneider T. Feedback of atmosphere-ocean coupling on shifts of the intertropical convergence zone. Geophys Res Lett.
2017;44(22):11,644-11,653. https://doi.org/10.1002/2017GL07 5817.

144. Green B, Marshall J. Coupling of trade winds with ocean circulation damps ITCZ shifts. J Climate. 2017;30(12):43954411. https://doi.org/10.1175/JCLI-D-16-0818.1.

145. Kang SM, Shin Y, Xie SP. Extratropical forcing and tropical rainfall distribution: energetics framework and ocean Ekman advection. npj Clim. Atmos Sci. 2018;1(1):20,172. https://doi.org/10.1038/s41612-017-0004-6.

146. Xie PP, Arkin PA. Analyses of global monthly precipitation using gauge observations satellite estimates, and numerical model prediction. J Climate. 1996;9:840-858.

147. Xie PP, Arkin PA. Global precipitation: A 17-year monthly analysis based on gauge observations, satellite estimates, and numerical model outputs. Bull Amer Meteor Soc. 1997;78:2539_ 2558.

148. Adler RF, Huffman GJ, Chang A, Ferraro R, Xie P, Janowiak J, Rudolf B, Schneider U, Curtis S, Bolvin D, Gruber A, Susskind J, Arkin P, Nelkin EJ. The Version-2 Global Precipitation Climatology Project (GPCP) monthly precipitation analysis (1979-present). J Hydrometeor. 2003;4(6):1147-1167.

149. Huffman GJ, Adler RF, Bolvin DT, Gu G. Improving the global precipitation record: GPCP Version 2.1. Geophys Res Lett. 2009;36:L17,808. https://doi.org/10.1029/2009GL040000.

150. Kay JE, Deser C, Phillips A, Mai A, Hannay C, Strand G, Arblaster JM, Bates SC, Danabasoglu G, Edwards J, Holland M, Kushner P, Lamarque JF, Lawrence D, Lindsay K, Middleton A, Munoz E, Neale R, Oleson K, Polvani L, Vertenstein M. The Community Earth System Model (CESM) large ensemble project: a community resource for studying climate change in the presence of internal climate variability. Bull Amer Meteor Soc. 2015;96:1333-1349. https://doi.org/10.1175/JCLID-11-00015.1.

Publisher's Note Springer Nature remains neutral with regard to jurisdictional claims in published maps and institutional affiliations.

\title{
Affiliations
}

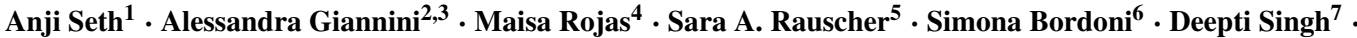 \\ Suzana J. Camargo 8
}

1 Department of Geography, University of Connecticut, Storrs, CT, USA

2 International Research Institute for Climate and Society, The Earth Institute at Columbia University, Palisades, NY, USA

3 Laboratoire de Météorologie Dynamique, Ecole Normale Supérieure, Paris, France

4 University of Chile, Santiago, Chile

5 Department of Geography, University of Delaware, Newark, DE, USA

6 Environmental Science and Engineering, California Institute of Technology, Pasadena, CA, USA

7 School of the Environment, Washington State University, Vancouver, WA, USA

8 Lamont-Doherty Earth Observatory, Columbia University, Palisades, NY, USA 